\title{
Corrigendum to "Change of Anesthesia Management for a Patient Undergoing CABG by an Incidental Finding of a Genetic Variant Associated with Malignant Hyperthermia"
}

\author{
Trey B. Creech (D) and Li Zhang \\ Anesthesiology Department, Geisinger Medical Center, Danville, PA, USA \\ Correspondence should be addressed to Trey B. Creech; tbcreech@geisinger.edu \\ Received 14 October 2019; Accepted 21 October 2019; Published 20 November 2019 \\ Copyright (C) 2019 Trey B. Creech and Li Zhang. This is an open access article distributed under the Creative Commons Attribution \\ License, which permits unrestricted use, distribution, and reproduction in any medium, provided the original work is properly \\ cited.
}

In the article titled "Change of Anesthesia Management for a Patient Undergoing CABG by an Incidental Finding of a Genetic Variant Associated with Malignant Hyperthermia" [1], the sentence "At our institution, we do not routinely refer patients with genetic variants associated with $\mathrm{MH}$ for muscle contracture testing," should be removed from the Discussion, where the third paragraph should read as follows:

"Muscle contracture testing may help confirm suspected pathogenic genes associated with MH. However, the muscle contracture testing has a sensitivity of $92-97 \%$ with specificity of only $53-78 \%$ for the North American Malignant Hyperthermia Group [8]".

\section{Reference}

[1] Trey B. Creech and Li Zhang, "Change of anesthesia management for a patient undergoing $\mathrm{CABG}$ by an incidental finding of a genetic variant associated with malignant hyperthermia," Case Reports in Anesthesiology, vol. 2019, Article ID 3189719, 3 pages, 2019. 


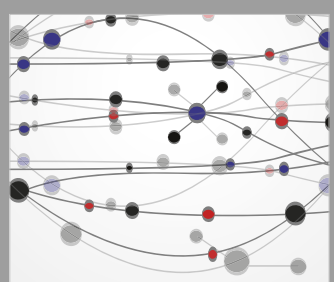

The Scientific World Journal
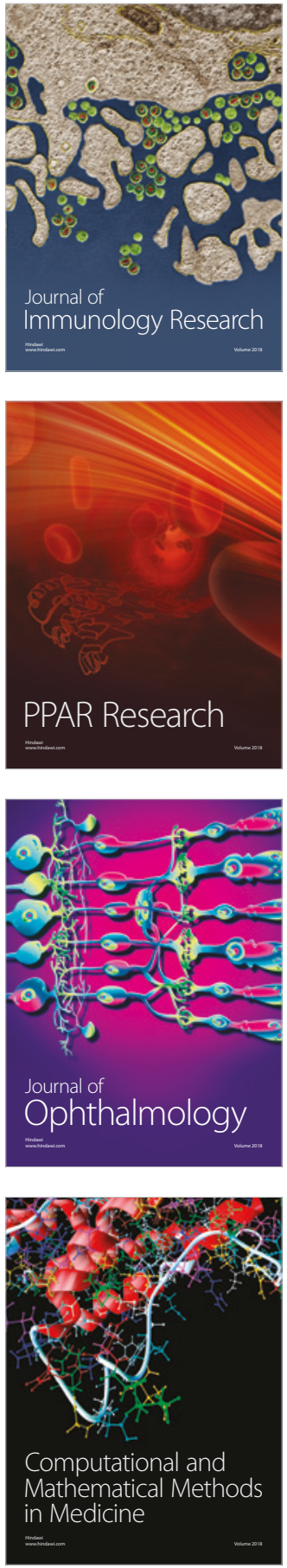

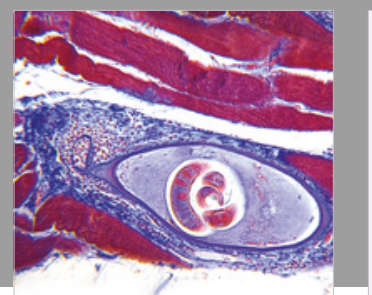

Gastroenterology Research and Practice

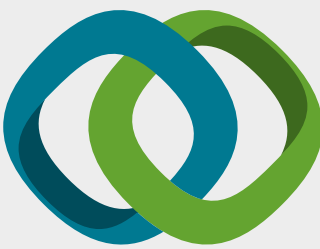

\section{Hindawi}

Submit your manuscripts at

www.hindawi.com
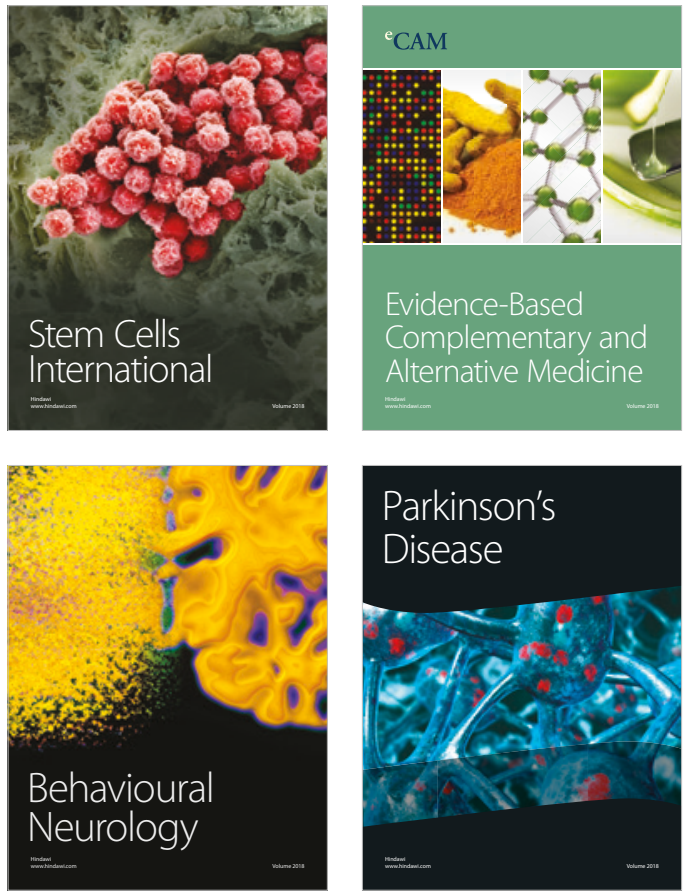

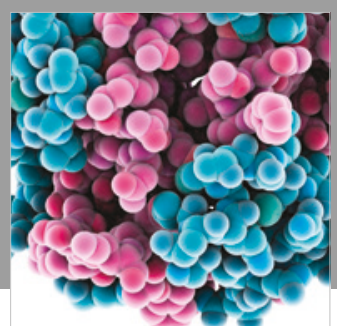

ournal of

Diabetes Research

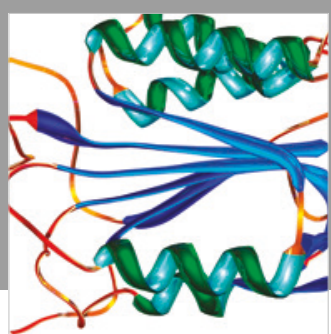

Disease Markers
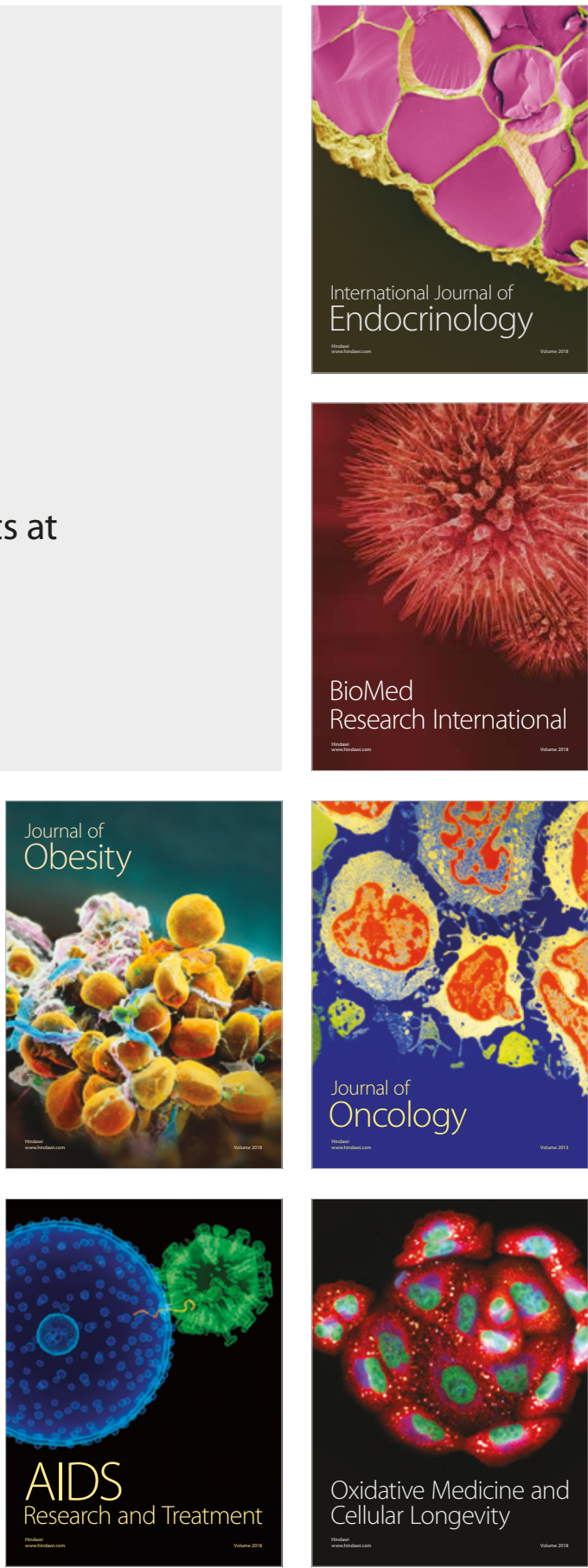